\title{
Free-living Acanthamoeba and Naegleria spp. amebae in water sources of León, Nicaragua
}

\author{
Byron Leiva ${ }^{1,2,3}$, Emma Clasdotter ${ }^{2}$, Ewert Linder ${ }^{2,3} \&$ Jadwiga Winiecka-Krusnell ${ }^{3}$ \\ 1. Departamento de Microbiología y Parasitología, Universidad Nacional Autónoma de Nicaragua, León, Nicaragua. Tel. \\ 505-311 2947. Fax: 505-311 2947; byronleiva2001@yahoo.com.mx; byron.leiva@smi.ki.se \\ 2. Microbiology and Tumor Biology Centre, Karolinska Institute, SE-171 77, Stockholm, Sweden; ewert.linder@smi.ki.se \\ 3. Department of Parasitology, Mycology and Environmental Microbiology, Swedish Institute for Infectious Disease \\ Control, SE-171 82 Solna, Sweden. Tel. +46-8-4572521. Fax +46-8-310525; jadwiga.winiecka-krusnell@smi.ki.se
}

\section{Received 16-I-2007. Corrected 20-IX-2007. Accepted 04-X-2007.}

\begin{abstract}
FLA) are known to occur worldwide in water-related biotopes, but only limited information is available on these organisms in developing countries and so far no information on their presence is available from Nicaragua. The aims of this study were to evaluate the prevalence of potentially pathogenic Acanthamoeba spp. and Naegleria spp. in different water sources to which the population of León municipality is exposed. Since pathogenic amebae are thermotolerant, we were especially interested in the occurrence of FLA in geothermal areas. Water samples were collected from León area in Nicaragua: 88 samples were from rivers and springs, 111 from wells, 74 from water taps and 21 from water tanks in urban and suburban León and from three nearby geothermal areas of San Jacinto, Posoltega and Tipitapa. Amebae were identified using morphological and physiological criteria, immunohistochemical staining procedures and molecular methods. Indirect immunofluorescent test was performed on cysts and trophozoites fixed on microscopical slides and incubated for $30 \mathrm{~min}$ at room temperature in separate experiments with the following antibodies: rabbit-anti $N$. fowleri/N. lovanensis (Nf-Pab), mouse monoclonal antibody anti $N$. fowleri $(\mathrm{Nf}-5 \mathrm{D} 12 \mathrm{u})$, rabbit antibodies against Acanthamoeba spp. And fluorescent in situ hybridization (FISH) was performed using 18S rRNAtargeted fluorescent oligonucleotide probes. Probes: GSP for the detection of Acanthamoeba and NAEG1088 for the detection of Naegleria. Free-living amebae were recovered from approximately $43 \%$ of the samples. Acanthamoeba spp was found in $21 \%$ of samples from León municipality and in $2 \%$ of samples from geothermal areas. Amoeboflagellates were found in $10 \%$ of samples from León and in $19 \%$ in geothermal areas. Fifty three percent of tested wells in the geothermal area contained thermotolerant amoeboflagellates. Naegleria spp. was identified in 24 out of $39(61.5 \%)$ of isolated amoeboflagellates. Twelve of them were assigned to $N$. lovanenesis while none of the isolates could be identified as $N$. fowleri. However, the common presence of thermotolerant Naegleria in water, specially $N$. lovanensis, which is an indicator species for $N$. fowleri, suggests that also this pathogenic amoeba may pose a risk to public health in the area. On the other side, direct pathogenicity, free-living amebae are receiving increasing attention as reservoirs and potential vehicles for the transmission of bacteria in the environment. Thus the information provided in this study may serve as base-line for future studies on the role of free-living amebae e.g. in waterborne-disease outbreaks in the region. Among such potentially important enteropathgens are Vibrio cholerae, E. coli 0157, and Helicobacter pylori. Rev. Biol. Trop. 56 (2): 439-446. Epub 2008 June 30.
\end{abstract}

Key words: free-living amebae, amebic encephalitis, amebic keratitis; Acanthamoeba, Naegleria, water sanitation.

Free-living amebae (FLA) are a large group of organisms with worldwide distribution. Humans are naturally exposed to these amebae since they are common in the environment, especially in all water-related biotopes. Among FLA there are facultative parasites of man and animals belonging to genera Acanthamoeba, Naegleria and Balamuthia 
causing severe infections in the central nervous system. Acanthamoeba spp. are also capable of infecting the skin, the lungs, the eyes or causing disseminated infections in susceptible hosts, immunodeficiency apparently being an increasingly important risk factor (Visvesvara 1993, De Jonckheere 1980, De Jonckheere and Brown 1997, Senazsi et al. 1998, MaracianoCabral et al. 2000).

Notably Naegleria spp. grow preferentially in water temperatures of 25 to $44{ }^{\circ} \mathrm{C}$. This parasite is potentially pathogenic in man causing fatal primary amoebic meningoencephalitis (PAM). Typically children and young adults are the victims and most cases have been described from the United States, Australia and the Check republic. In Nicaragua, geothermal areas are frequently used for recreation, and thermal water may be the only water source of local households. However, there is no information on the presence of potentially pathogenic free-living amebae in the region. Also it is not surprising that cases of PAM have not been described in Nicaragua, considering the difficulties in establishing the diagnosis by cytological analysis (Benson et al. 1985) and the restricted availability of NMR (Falcone et al. 1994). Importantly diagnostic difficulties occur even under favorable health care conditions (Hecht et al. 1972, Bakardjiev et al. 2002, Gyori 2003, Stephany et al. 2004).

The aims of this study were to evaluate the prevalence of FLA in different sources of water in the urban area of León municipality and in the geothermal area, and search for thermotolerant, potentially pathogenic Acanthamoeba spp. and Naegleria spp. in the isolated material. Collected data will serve as a base-line information for future studies on association between FLA and clinical conditions caused by these organisms. Furthermore such information may be important considering outbreaks of diarrhea caused by enteropathogenic bacteria in water.

\section{MATERIALS AND METHODS}

Sample collection and cultivation of amebae: water samples were collected from León area in Nicaragua: 88 samples were from rivers and springs, 111 from wells, 74 from water taps and 21 from water tanks in urban and suburban León and from 3 nearby geothermal areas of San Jacinto, Posoltega and Tipitapa.

Water samples were collected into sterile $50 \mathrm{ml}$ tubes and transported to the laboratory at Microbiology Department, University of León were they were studied using established methods for identification essentially as described (Schuster 2002). Amebae were isolated from specimens filtered through $0.45 \mu \mathrm{m}$ filters attached to sterile syringes. Filters were placed on non-nutrient agar plates covered with viable Escherichia coli K12 strain. Part of the samples were centrifuged for $10 \mathrm{~min}$ at $4000 \mathrm{rpm}$, supernatant was removed and the sediment was re-suspended with remaining water by tapping the tube. One or two drops were placed on agar-E. coli plates. Agar plates were incubated at $40{ }^{\circ} \mathrm{C}$ for the isolation of thermotolerant strains. Growing amebae were repeatedly subcultured and cloned by limiting dilution.

Reference strains: strains of Acanthamoeba castellanii, A. rhysodes, Hartmannella vermiformis, Naegleria gruberi and N. lovanensis. The ocular Acanthamoeba strains were isolated at SMI and typed at PHL, Bath, England. Hartmannella was obtained from Dr. E. Hadas, University of Poznan, Poland and Naegleria gruberi from ATCC Atlanta. Amebae were cultivated on non-nutrient agar plates covered with E. coli and used as control material for identification tests.

Identification of isolates: initial identification of amebae was based on microscopical observation of living and fixed cysts and trophozoites. Measurements were performed with an ocular micrometer at $400 \mathrm{x}$ and 1000 $\mathrm{x}$ magnification. Data from 50 individuals of each strain were collected and characterization was made using morphological criteria. Thermotolerance of amebae was assessed by testing for ability to grow on agar plates incubated at $40,42,45$ and $47{ }^{\circ} \mathrm{C}$ for five to seven days. The enflagellation test (Behets et 
al. 2003) was performed on 24-wells plates. Trophozoites collected from agar plates were added to wells containing two $\mathrm{ml}$ of sterile, distilled water and incubated at $37{ }^{\circ} \mathrm{C}$. The plates were inspected after 30,60, 90 and $120 \mathrm{~min}$ for the presence of free-swimming, flagellated forms. Indirect immunofluorescent test was performed on cysts and trophozoites fixed on microscopical slides and incubated for $30 \mathrm{~min}$ at room temperature in separate experiments with the following antibodies: rabbit-anti $N$. fowleri/N. lovanensis (Nf-Pab), mouse monoclonal antibody anti $N$. fowleri (Nf-5D12u) (both from Indicia Biotechnology, Oullins, France), rabbit antibodies against Acanthamoeba spp. (were from Dr J-Å Liljeqvist, University of Gothenburg, Sweden). After washing with PBS slides were incubated again for $30 \mathrm{~min}$ at room temperature with the appropriate FITC conjugated sheep anti-rabbit anti-immunoglobulin antibodies (Sigma F 1010, Saint Louis, Missouri). After subsequent washing with PBS, slides were mounted in non-fading medium (Vectashield, Vector laboratories, Inc. Burlingame, CA.) and observed in the microscope. The presence of cellulose in cyst wall of Acanthamoeba was demonstrated using the cellulose-binding domain of cellulase essentially as described (Linder et al. 2002). Fluorescent in situ hybridization (FISH) was performed using 18S rRNA- targeted fluores- cent oligonucleotide probes according to the protocols described before (Grimm et al. 2001, Stothard et al. 1999). Probes: GSP for the detection of Acanthamoeba and NAEG1088 for the detection of Naegleria were synthesized by Scandinavian Gene Synthesis AB, 73122 Köping, Sweden.

\section{RESULTS}

One hundred twenty five out of the 294 samples (42.5\%) collected from different water sources yielded growth of FLA. Amebae could be recovered from 75 out of $178(42 \%)$ water samples collected in the León municipality and an almost identical proportion was recovered from samples from the geothermal areas (50 out of $116.43 \%$ ) (Table 1 and 2). However, a detailed analysis showed some differences; the lowest prevalence of amebae, 17 out of 74 $(23 \%)$ was found in tap water in León municipality and the highest prevalence in wells from geothermal areas, 25 out of $36(69 \%)$, (Table 1 and 2). There were significantly higher levels of amoeboflagellates from wells in geothermal areas as compared to wells in the León municipality, $53 \%$ as opposed to $15 \%$.

The majority of samples contained multiple species of amebae, however, only Acanthamoeba and amebae developing flagellated forms, were considered in this study.

TABLE 1

Samples from León municipality in Nicaragua

\begin{tabular}{|c|c|c|c|c|c|c|}
\hline \multirow{2}{*}{ Sources } & \multirow{2}{*}{$\mathrm{N}^{\circ}$} & \multirow[t]{2}{*}{$\begin{array}{c}\text { Acanthamoeba spp. } \\
(\%)\end{array}$} & \multirow[t]{2}{*}{$\begin{array}{c}\text { Amoeboflagellates } \\
(\%)\end{array}$} & \multirow{2}{*}{$\begin{array}{l}{ }^{1} \text { Other } \\
(\%)\end{array}$} & \multicolumn{2}{|c|}{ Total pos } \\
\hline & & & & & $\mathrm{N}^{\circ}$ & $(\%)$ \\
\hline Water tank & 21 & (29) & (5) & (10) & 9 & 43 \\
\hline Tap water & 74 & (19) & (4) & $(0)$ & 17 & 23 \\
\hline Wells & 75 & (21) & (15) & (21) & 43 & 57 \\
\hline Stream & 8 & (13) & (25) & (38) & 6 & 75 \\
\hline Total & 178 & (21) & (10) & (12) & 75 & 42 \\
\hline
\end{tabular}

1 Other $=$ Hartmanella sp., Free living amoebae not identified. pos $=$ positive 
TABLE 2

Samples from geothermal areas in Nicaragua

\begin{tabular}{|c|c|c|c|c|c|c|}
\hline \multirow{2}{*}{ Sources } & \multirow{2}{*}{$\mathrm{N}^{\circ}$} & \multirow{2}{*}{$\begin{array}{c}\text { Acantahamoeba spp. } \\
\%\end{array}$} & \multirow{2}{*}{$\begin{array}{c}\text { Amoebaflagellalates } \\
(\%)\end{array}$} & \multirow{2}{*}{$\begin{array}{l}{ }^{1} \text { Other } \\
(\%)\end{array}$} & \multicolumn{2}{|c|}{ Total pos } \\
\hline & & & & & $\mathrm{N}^{\circ}$ & $(\%)$ \\
\hline Wells & 36 & (0) & (53) & (17) & 25 & 69 \\
\hline Stream & 80 & (5) & (8) & (25) & 25 & 3 \\
\hline Total & 116 & (2) & (19) & (22) & 50 & 43 \\
\hline
\end{tabular}

$1 \quad$ Other $=$ Hartmanella sp., Free living amoebae not identified pos. $=$ positive

TABLE 3

Growth of thermotolerant free-living amebae at different temperatures

\begin{tabular}{lcccccc} 
& \multicolumn{3}{c}{ Acanthamoeba } & \multicolumn{3}{c}{ Amoebaflagellates } \\
& $40^{\circ} \mathrm{C}$ & $42^{\circ} \mathrm{C}$ & $\geq 45^{\circ} \mathrm{C}$ & $40^{\circ} \mathrm{C}$ & $42^{\circ} \mathrm{C}$ & $\geq 45^{\circ} \mathrm{C}$ \\
León Municipality & 32 & 5 & 0 & 9 & 8 & 0 \\
Geothermal areas & 2 & 0 & 0 & 6 & 5 & 11 \\
Total & 34 & 5 & 0 & 15 & 13 & 11
\end{tabular}
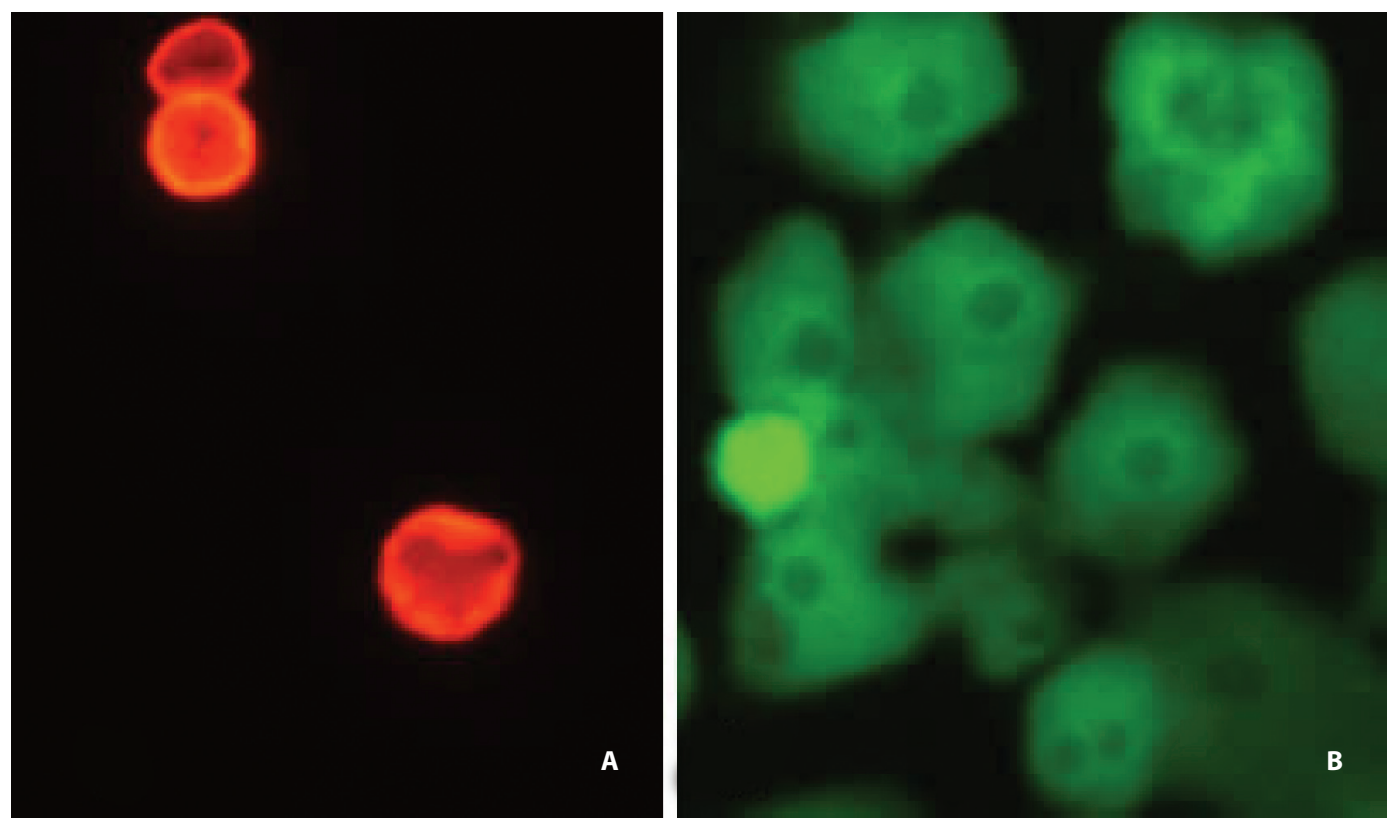

Fig. 1.A Identification of cyst of Acanthamoeba spp. stained with monoclonal anti-cellulase antibodies. (B) Indentification of Acanthamoeba spp. by fluorescence in situ hybridization (FISH) with 18S rRNA gene specific probe. 
TABLE 4

Identification of Naegleria isolates by different methods

$\begin{array}{lccccc} & \text { Enflagellation } & \text { FISH } & \geq 42{ }^{\circ} \mathrm{C} & \text { Nf-Pab } & \text { Nf-5D12u } \\ \text { León Municipality } & 17 & 8 & 8 & 3 & 0 \\ \text { Geothermal areas } & 22 & 16 & 16 & 9 & 0 \\ \text { Total } & 39 & 24 & 24 & 12 & 0\end{array}$

FISH $=$ fluorescent in situ hybridization

IF $=$ immunofluorescence microscopy

$\mathrm{Nf}-\mathrm{Pab}=$ anti $N$. fowleri $/ N$. lovanensis polylconal antibodies

$\mathrm{Nf}-5 \mathrm{D} 12 \mathrm{u}=\operatorname{anti} N$. fowleri mouse monoclonal antibodies
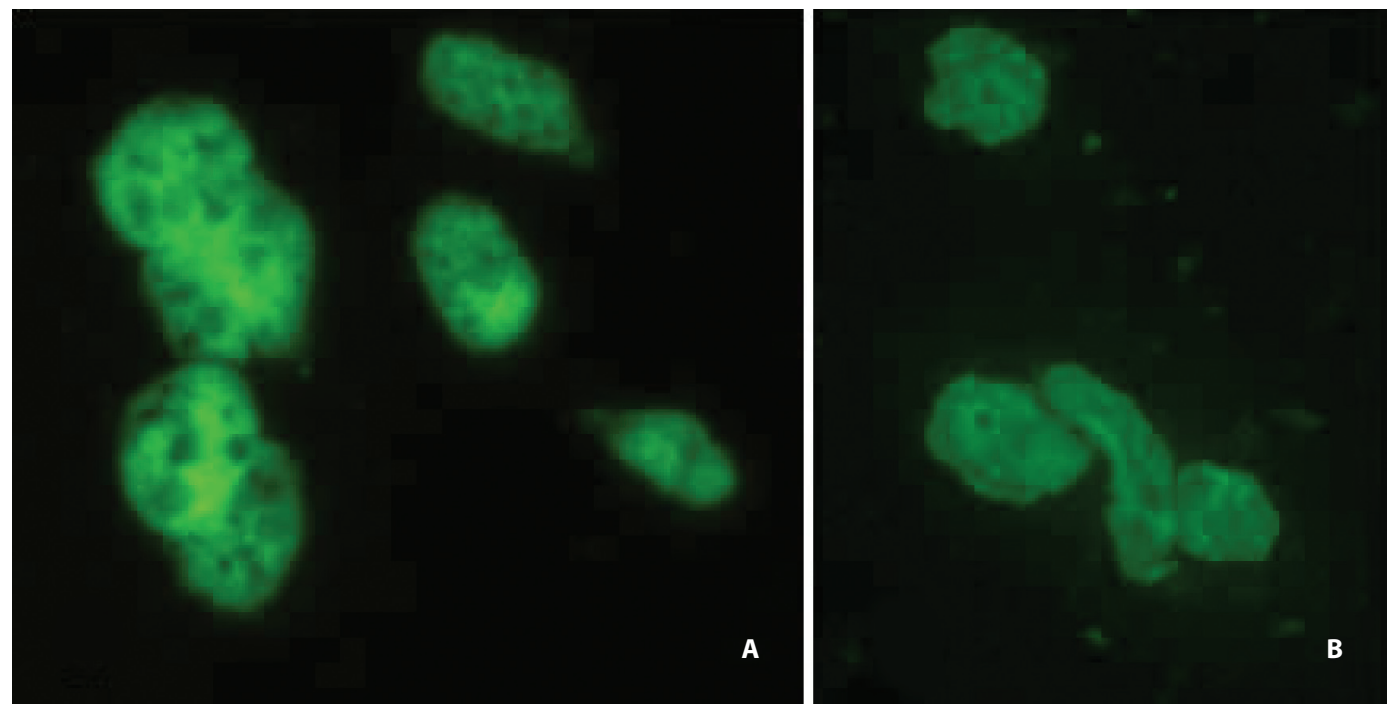

Fig. 2. A. Identification of Naegleria spp. by FISH with 18S rRNA Naegleria probe. (B) Identification of Naegleria with polyclonal rabbit-anti $N$. fowleri/N. lovanensis $(\mathrm{Nf}-\mathrm{Pab})$ by indirect immunofluorescence.

The average water temperature of samples collected in the area of León was $27.5{ }^{\circ} \mathrm{C}$ while the temperature of water collected in San Jacinto, Posoltega and Tipitapa was $38.5{ }^{\circ} \mathrm{C}$ ranging from $34-50{ }^{\circ} \mathrm{C}$. Thermotolerant amebae growing at $\geq 40{ }^{\circ} \mathrm{C}$ were identified among both Acanthamoeba and amoeboflagellate isolates. Recovery of amebae was similar in the 3 geothermal areas. Half of the amoeboflagellates, 11 out of 22 isolated from the geothermal areas, showed growth at temperatures $\geq 45{ }^{\circ} \mathrm{C}$ (Table 3).

Thirty-nine isolates $(31.2 \%$ of positive samples) were classified as Acanthamoeba spp. by applying morphological criteria. Their identity was further confirmed by reactivity of trophozoites with anti- Acanthamoeba antibodies, the presence of cellulose in their cysts and by the FISH technique. All 39 isolates were positive by all methods used for identification.

Twenty-four flagellated isolates $(19.2 \%$ of positive samples) were classified as Naegleria spp. based on positive FISH with Naegleria specific probe. Twelve isolates $(50 \%)$ were tentatively assigned to $N$. lovanensis based on the reactivity with Nf-Pab antibody (Table 4, Fig. 2), as all 12 failed to react with $N$. fowleri specific monoclonal Nf-5D12u antibodies. 


\section{DISCUSSION}

The results in this study show that potentially pathogenic FLA are common in the León area and widely distributed even in drinking water. Morphological criteria and cultivation at different temperatures form the basis for species identification. It is known that the pathogenicity of FLA correlates with their capacity to tolerate temperatures of $37{ }^{\circ} \mathrm{C}$ or more (De Jonckheere 1980) and that non-virulent and non-pathogenic strains are unable to grow at temperatures above $37^{\circ} \mathrm{C}$ (Visvesvara 1993).

All tests for Acanthamoeba were consistently positive. This is true also for the cellulase binding method described by us (Linder et al. 2002). The enflagellation test is used to identify genus Naegleria. However, when the detection of Naegleria spp. is based on the enflagellation test, false negatives are likely to occur, leading to significant underestimations (Behets et al. 2003) Specific PCR probes for Naegleria are valuable tools for the identification of environmental protozoa (Grimm et al. 2001). Apparently a higher sensitivity is achieved using such methods. Thus it was possible to detect $N$. fowleri in Yellowstone and Grand Teton National parks by PCR, which was not the case in a pervious study using conventional cultivation and microscopy methods (Sheehan et al. 2003).

In our study FLA were found in $43 \%$ of water samples studied. Such a high prevalence is not unique. In a recent study from Bulgaria, the prevalence was $61 \%$ in natural fresh waters and in river samples as high as 94\% (Tsvetkova et al. 2004). In Germany Acanthamoeba was found in $79 \%$ of isolates of river water (Hoffmann and Michel 2001). That tap water may contain FLA has been well documented by analyzing the different steps of water purification (Hoffmann and Michel 2001). Also our unpublished studies showed that water treatment procedures employed at the local municipal water supplier in the Stockholm region, Stockholm water, fail to eliminate Acanthamoeba, it is well established that whereas Acanthamoeba spp. are common in natural and tap water glob- ally, presence of Naegleria spp. is restricted to areas with naturally warm water (John 1982). The increasing use of contact lenses and the difficulties involved in maintaining their sterility, makes the presence of Acanthamoeba in human environments a potential threat. There is accumulating information on the prevalence of FLA in areas with a hot climate (Lawande 1983, Ugonabo and Gugani 1989, Rivera et al. 1989, Bose et al. 1990, Hamado et al. 1993, Da Silva and Da Rosa 2003). However, little is known about the occurrence of Acanthamoeba keratitis in poor countries such as Nicaragua.

In thermal areas we found significantly more Naegleria than Acanthamoeba. Such environmental conditions occur in geothermal areas globally, but may occur also in the environment, which has been heated by other means. Raised temperatures during the hot summer months or warm water from power plants facilitate the growth of $N$. fowleri (Martinez and Visvesvara 1997). However, in the cyst form these protozoa are extremely resistant and may occur in dust (Lawande 1983, Da Silva and Da Rosa 2003).

Reports of fatal meningo-encephalitis due to $N$. fowleri in geothermally heated water in Australia, and in Bath, England, have imposed restrictions in the usage of natural warm water for recreational purposes. That the presence of Naegleria in our environment poses a real threat is reflected by research aiming at inactivation of amoebae in large volumes of fresh water (Vernhes et al. 2002).

In addition to their direct pathogenicity, free-living amebae are receiving increasing attention as reservoirs and potential vehicles for the transmission of bacteria in the environment. Thus the information provided in this study may serve as base-line for future studies on the role of free-living amebae e.g. in waterborne-disease outbreaks in the region. Among such potentially important enteropathogens are Vibrio cholerae, E. coli 0157 , and Helicobacter pylori (King et al. 1988, Winiecka-Krusnell et al. 2001, Barker et al. 2002).

In summary, our study showed that Acanthamoeba and Naegleria are found 
regularly in León municipality and that Naegleria is common in the geothermal area studied. The common presence of $N$. lovanensis, which is an indicator species for $N$. fowleri suggests that recreational water contact in thermal area may pose a risk to public health.

\section{ACKNOWLEDGMENTS}

We thank students of the UNAN-León for participation in the collection of the water samples and Brenda Mora for laboratory work. This study was supported by the Swedish Agency for Research Cooperation with Developing Countries (SAREC).

\section{RESUMEN}

Las amebas de vida libre (AVL) son un grupo de organismos de distribución mundial. Entre las AVL hay parásitos facultativos en humanos y otros animales, los cuales pertenecen a los géneros Acanthamoeba, Naegleria y Balamuthia que causan infecciones severas en el sistema nervioso central. Sin embargo no se tiene ninguna información de Nicaragua. El objetivo de este estudio fue evaluar la presencia de amebas de vida libre, en diferentes fuentes de agua de la parte urbana y rural del Departamento de León, y áreas geotérmicas de Nicaragua. Estas amebas fueron identificadas usando criterios morfológicos, fisiológicos, histoquímicos y moleculares. En los resultados se encontró amebas de vida libre en el $43 \%$ del total de las muestras. En la municipalidad de León, se encontraron $21 \%$ de Acanthamopeba sp. y en las áreas geotérmicas un $2 \%$. Las amebaflagelados tipo Naegleria fueron $10 \%$ y $19 \%$ respectivamente. Del grupo amebaflagelados fueron 24, de las cuales 12 se dentificaron como $N$. lovanensis. En estas muestras no se aisló $N$. fowleri (ameba patógena), sin embargo, la presencia de $N$. lovanensis es in indicador de la presencia de $N$. fowleri, la cual puede ser un riesgo a la salud pública. Además, estas amebas pueden servir como vectores de bacterias enteropatógenas.

Palabras claves: amebas de vida libre, encefalitis amebiana, queratitis amebiana, Acanthamoeba, Naegleria, saneamiento de agua.

\section{REFERENCES}

Bakardjiev, A., C. Glaser, F. Schuster \& G.S. Visvesvara. 2002. Three-year-old girl with fever and coma. Pediatr. Infect. Dis. J. 21: 85-6.
Barker, J., T.J. Humphrey \& M.W.R. Brown. 1999. Survival of Escherichia coli 0157 in a soil protozoan: implications for disease. FEMS Microbiol. Lett. 173: 291-295.

Behets, J., F. Seghi, P. Declerck, L. Verelst, L. Duvivier, A. Van Damme \& F. Ollevier. 2003. Detection of Naegleria spp. and Naegleria fowleri: a comparison of flagellation tests, ELISA and PCR. Water Sci. Technol. 47: 117-122.

Benson, R.L., L. Ansbacher, R.E. Hutchison \& W. Rogers. 1985. Cerebrospinal fluid centrifuge analysis in primary amebic meningoencephalitis due to Naegleria fowleri. Arch. Pathol. Lab. Med. 109: 668-671.

Bose, K., D. Ghosh, K. Ghosh, A. Bhattacharya \& S. Das. 1990. Characterization of potentially pathogenic freeliving amebae in sewage samples of Calcutta, India. Braz. J. Med. Biol. Res. 23: 1271-1278.

Da Silva, M.A. \& J.A. Da Rosa. 2003. Isolation of potentially pathogenic free-living amoebas in hospital dust. Rev. Saude Publica, 37: 242-246.

De Jonckheere, J. 1980. Growth characteristics, cytopathic effect in cell culture, and virulence in mice of 36 type strains belonging to 19 different Acanthamoeba spp. Appl. Environ. Microbiol. 39: 681-685.

De Jonckheere, J.F. \& S. Brown. 1997. Primary amebic meningoencephalitis in a patient with AIDS: unusual protozoological findings. Clin. Infect. Dis. 25: 943-944.

Falcone, S., R.M. Quencer \& M.J. Post. 1994. Magnetic resonance imaging of unusual intracranial infections. Top. Magn. Reson. Imaging 6: 41-52.

Grimm, D., W.F. Ludwig, B.C. Brandt, R. Michel, K.H. Schleifer, J. Hacker \& M. Steinert. 2001. Development of 18S rRNA-targeted oligonucleotide probes for specific detection of Hartmannella and Naegleria in Legionella-positive environmental samples. Syst. Appl. Microbiol. 24: 76-82.

Gyori, E. 2003. December 2002: 19-year old male with febrile illness after jet ski accident. Brain Pathol. 13: 237-239.

Hamado, H., S. Aufy, I. el-Hayawan, M. Saleh \& I. Nagaty. 1993. Study of free-living amebae in Egypt. J. Egypt Soc. Parasitol. 23: 631-637.

Hecht, R.H., A.H. Cohen, J. Stoner \& C. Irwin. 1972. Primary amebic meningoencephalitis in California. Calif. Med. 117: 69-73. 
Hoffmann, R. \& R. Michel. 2001. Distribution of freeliving amebae (FLA) during preparation and supply of drinking water. Int. J. Hyg. Environ. Health 203: 215-219.

John, D.T. 1982. Primary amebic meningoencephalitis and the biology of Naegleria fowleri. Annu. Rev. Microbiol. 36: 101-123.

King, C.H., E.B. Jr. Shotts, R.E. Wooley \& K.G. Porter. 1988. Survival of coliforms and bacterial pathogens within protozoa during chlorination. Appl. Environ. Microbiol. 54: 3023-3033.

Lawande, R.V. 1983. Recovery of soil amoebae from the air during the harmattan in Zaria, Nigeria. Ann. Trop. Med. Parasitol. 77: 45-49.

Linder, M., J. Winiecka-Krusnell \& E. Linder. 2002. Use of recombinant cellulose-binding domains of Trichoderma reesei cellulase as a selective immunocytochemical marker for cellulose in protozoa. Appl. Environ. Microbiol. 68: 2503-2508.

Marciano-Cabral, F., R. Puffenbarger \& G.A. Cabral. 2000. The increasing importance of Acanthamoeba infections. J. Eukaryot. Microbiol. 47: 29-36.

Martinez, A.J. \& G.S. Visvesvara.1997. Free-living, amphizoic and opportunistic amebas. Brain Pathol. 7: $583-598$.

Rivera, F., F. Lares, E. Gallegos, E. Ramirez, P. Bonilla, A. Calderon, J.J. Martinez, S. Rodriguez \& J. Alcocer. 1989. Pathogenic amebae in natural thermal waters of three resorts of Hidalgo, Mexico. Environ. Res. 50: 289-295.

Schuster, F.L. 2002. Cultivation of pathogenic and opportunistic free-living amebas. Clin. Microbiol. Rev. 15: 342-354.

Sheehan, K.B., J.A. Fagg, M.J. Ferris \& J.M. Henson. 2003. PCR detection and analysis of the free-living amoeba Naegleria in hot springs in Yellowstone and Grand Teton National Parks. Appl. Environ. Microbiol. 69: 5914-5918.

Stephany, J.D., G.S. Pearl \& O.R. Gonzalez. 2004. Pathologic quiz case: headache in an 8 year old child. Primary amebic meningoencephalitis due to Naegleria fowleri. Arch. Pathol. Lab. Med. 128: 33-34.

Stothard, D.R., J. Hay, J.M. Schroeder-Diedrich, D.V. Seal \& T.J. Byers. 1999. Fluorescent oligonucleotide probes for clinical and environmental detection of Acanthamoeba and the T4 18S rRNA gene sequence type. J. Clin. Microbiol. 37: 2687-2693.

Szenasi, Z., T. Endo, K. Yagita \& E. Nagy. 1998. Isolation, identification and increasing importance of 'freeliving' amebae causing human disease. J. Med. Microbiol. 47: 5-16.

Tsvetkova, N., M. Schild, S. Panaiotov, R. KurdovaMintcheva, B. Gottstein, J. Walochnik, H. Aspock, M.S. Lucas \& N. Muller. 2004. The identification of free-living environmental isolates of amebae from Bulgaria. Parasitol. Res. 92: 405-413.

Ugonabo, J. \& H. Gugani. 1989. Nasal carriage of Naegleria fowleri and its environmental occurrence in Boro state, Nigeria. J. Commun. Dis. 21: 111-113.

Visvesvara, G.S. 1993. Epidemiology of infections with free-living amebas and laboratory diagnosis of microsporidiosis. Mt. Sinai J. Med. 60: 283-288.

Vernhes, M.C., A. Benichou, P. Pernin, P.A. Cabanes \& J. Teissie. 2002. Elimination of free-living amoebae in fresh water with pulsed electric fields. Water Research 36: 3429-3438.

Winiecka-Krusnell, J. \& E. Linder. 2001. Bacterial infections of free-living amoebae. Res. Microbiol. 152: 613-619. 